\title{
Negative Total Float to Improve a Multi-objective Integer Non-linear Programming for Project Scheduling Compression
}

\author{
Fachrurrazi $^{1}$, Abdullah' ${ }^{2}$, Yuwaldi Away ${ }^{3}$, Teuku Budi Aulia ${ }^{4}$ \\ ${ }^{1,2,4}$ Department of Civil Engineering, Syiah Kuala University, Indonesia \\ ${ }^{3}$ Department of Electrical Engineering, Syiah Kuala University, Indonesia
}

\begin{abstract}
Article Info
Article history:

ABSTRACT

Received Mar 9, 2018

Revised Jul 18, 2018

Accepted Jul 31, 2018

\section{Keyword:}

Critical path method

Integer

Multi-objective

Negative total float

Nonlinear

Project schedule compression

Solver application

Time-cost function

This paper presents Multi-Objective Integer Non-Linear Programming (MOINLP) involving Negative Total Float (NTF) for improving the basic model of Multi-Objective Programming (MOP) in case the optimization of the additional cost for Project Scheduling Compression (PSC). Using the basic MOP to solve the more complex problems is a challenging task. We suspect that Negative Total Float (NTF) having an indication to make the basic MOP to solve the more general case, both simple and complex of PSC. The purpose of this research is identifying the conflicting objectives in PSC problem using NTF and improving MOINLP by involving the NTF parameter to solve the PSC problem. The Solver Application, which is an add-in of MS Excel, is used to perform optimization process to the model developed. The results show that NTF has an important role to identify the conflicting objectives in PSC. We define NTF is an automatic maximum value of the activity duration reduction to achieve due date of PSC. Furthermore, the use of NTF as a constraint in MOINLP can solve the more general case for both simple and complex PSC problem. Base on the condition, we state that the basic MOP is still significant to solve the PSC complex problems using MOINLP as a sophisticated MOP technique.
\end{abstract}

Copyright $\odot 2018$ Institute of Advanced Engineering and Science. All rights reserved.

\section{Corresponding Author:}

Fachrurrazi,

Doctoral Study Program of Engineering,

Syiah Kuala University, Aceh, Indonesia.

Email: fachrurrazi@unsyiah.ac.id

\section{INTRODUCTION}

In some of the projects cases emphasizing the schedule objective rather than the cost objective as a strategic project requiring immediately impact, will give the contractor a chance to propose the compression programme of the project schedule. The contractors should have a bargaining ability regarding the additional costs as a consequence of schedule compression that could have implications for win-win solutions to project parties. In contrast toward the projects costs as the main objective (main priority), the schedule compression as initiative of the contractor is mainly based on the reasons to demonstrate their performance to the owner [1] and to pursue completion time under contract due to delay in project implementation [2], [3] [4], etc. Generally, the PSC could be done by using two techniques, the fast track [5], crashing [6], or combining both techniques [7]. In recent decades, optimization is the important process and continuously improved to solve more complex problems in many fields that need to be satisfied, such as business portfolio [8], project management [9] and engineering applications. In proper sequence, it will provide the end user satisfaction regarding the problem solving and decision making [10].

A technique to obtain the optimal solution involving two or more conflicting objectives is known as Multi-Objective Programming (MOP). Some of the MOP that has been developed to solve the problem is seen as very complex and less practicable, like a genetic algorithm-based optimization [11]. But instead, using a basic model will only solve simple problems, like MOP by goal programming [12]. In the Project 
Scheduling Problem (PSC), using the basic MOP to solve the more complex problems is a challenging task. We have the opportunity to realize this challenging task by involving Negative Total Float (NTF) toward the basic MOP model and we call this model as MOINLP (Model Objective Integer Non-Linear Programming). MOINLP is used to solve the PSC case with integer variables on the high degree of non-linear time-cost function. Problem-solving the PSC having a nonlinear time cost model will contribute to a more complicated and dynamic of conflicting objective than a linear. Therefore, building a suitable model and its optimization algorithm will be an important task [13].

Understanding the conflicting objective and its causes on the PSC problem will make it easy for us to develop the innovative model to reach the problems solving [14], especially in case of the PSC optimization problem. Based on the background, the purposes of this research are to identify the conflicting objective of PSC problem and to develop MOINLP base on the basic model of PSC problem. A dataset of project case, as shown in Table 1, will be applied to conduct the testing of the proposed model in this paper. We use the Total Float parameter as an approach to identify the conflicting objectives of activities. The Total Float [15] in scheduling problem could have Zero Total Float (ZTF) are used to perform critical path analysis [16] and to identify the critical activity [17]; Positive Total Float (PTF) is the maximum allowable value of activities which does not cause delay of project [18]; and Negative Total Float (NTF) is used as a constraint of the proposed MOINLP model. Developing MOINLP in this paper has been adopted from the basic model in Deckro's paper [19], which is a simple/standard model to solve the linear case of multiobjective. Development of this prosed model is associated with NTF as the additional constraints model. Problem-solving of the PSC with a nonlinear model of the project activity is implemented using the Solver Application of Microsoft Excel add-ins.

Project scheduling compressing is a multi-objective problem involving the conflicting objective of several activities function, especially on critical activities. The conflicting objective will increase in line with the smaller due date caused by PSC. This research has been successfully involving NTF to identify the conflicting objective and to improve the performance of the basic MOP model called as MOINLP. This research has been developed to introduce NTF of activity as an indicator of activities that its duration can be reduced. This is in line with the LIM paper [16] but in this paper, we have brought the NTF as the important parameter to solve the PSC for both simple and complex problem. This research deliberately engineered NTF to know the activities to be accelerated. Furthermore, we define NTF as an automatic maximum value of the activity duration reduction. This is a novelty in this research. This research also utilizes the NTF to identify the conflicting objective of activity function in MOINLP.

The MOINLP is a development model of the basic MOP that refers to Deckro's paper [19] by involving NTF. We have simulated the MOINLP using the Solver Application to solve the PSC problem with the time-cost activities function by 2 to 6 degree. Applying the NTF to the basic MOP model for the complex problem of PSC is a novelty in this study. Relating the PSC, we state that the NTF is the maximum allowable value to reduce the activity duration in order to achieve the due date of the PSC. The results showed that there was a relationship between NTF and the activities which should be accelerated to obtain optimal solution dan feasible solution. Besides that, we have a presumption that NTF will improve the speed up of the optimization process as a future research for other researchers. We argue that NTF has an important role to generate the complex problem solving of MOINLP (non-linear function and high degree variables). This condition can be a starting point to refresh the use of a simple MOP model, as Deckro's research [19], but still has the power to solve the latest and more complex PSC problems.

\section{METHOD}

\subsection{Method Characteristic}

The method of identifying the conflicting objective of the activities in the PSC problem is proposed using an analysis of the NTF as a parameter of Total Float of activities. The Total Float analysis is based on the principle of the Critical Path Analysis. The Total Float of each activity could have a negative value as Negative Total Float (NTF), a positive value as Positive Total Float (PTF) [20], or even a zero value as Zero Total Float (ZTF) [20]. NTF of the project activity can occur if the latest finish (LF) is less than early finish $(\mathrm{EF})$ in the terminal node of the CPM network diagram. Where, the LF in a terminal node should be equal with the Project Crashing $(P c)$. The difference between the two parameters (LF and EF) is the value y of the PSC, as shown in Figure 3.

The method to solve the PSC is MOINLP model. The MOINLP is a development model of the basic concept of MOP referring Deckro's paper [19]. This MOP model will be developed and integrated by applying NTF, as an additional constraint for MOINLP model, to solve complex scheduling problems (this study will test the activities time-cost function of 2 to 6 degree). Developing the MOINLP algorithm needs to 
describe the operational performance of the CPM concept (Critical Path Method) [21]. The illustration of the CPM algorithm is shown in formula (1) through (10).

Applying the MOINLP model uses the Solver Application of Microsoft Excel Add-ins. The Solver Application is an optimization tool using the goal programming algorithm. The ease of the Solver is due to its simplicity in implementing mathematical models into tabulation and cells formula with more flexibility. Evolutionary Multi-Objective (EMO) method of the Solver will be used to problems requiring the integer output and smooth solution [22]. EMO can be used to solve single-objective optimization problems with a focus on finding a single optimal solution [23].

The use of the population in evolutionary multi-objective allows the Solver to have parallel searching ability to find multiple non-dominated solutions in a single iteration [13]. The Solver algorithms are based on a goal programming using the parameters of the objective function model (as target cell), constraints model (as subject to the constraints), and finding the value of variables (as changing cells) [24]. The framework for solving the PSC problem using the proposed MOINLP is described in the framework as shown in Figure 1. The MOINLP model will be applied to a project consisting of 12 non-linear functions of project activity (the function of 2 to 6 degree).

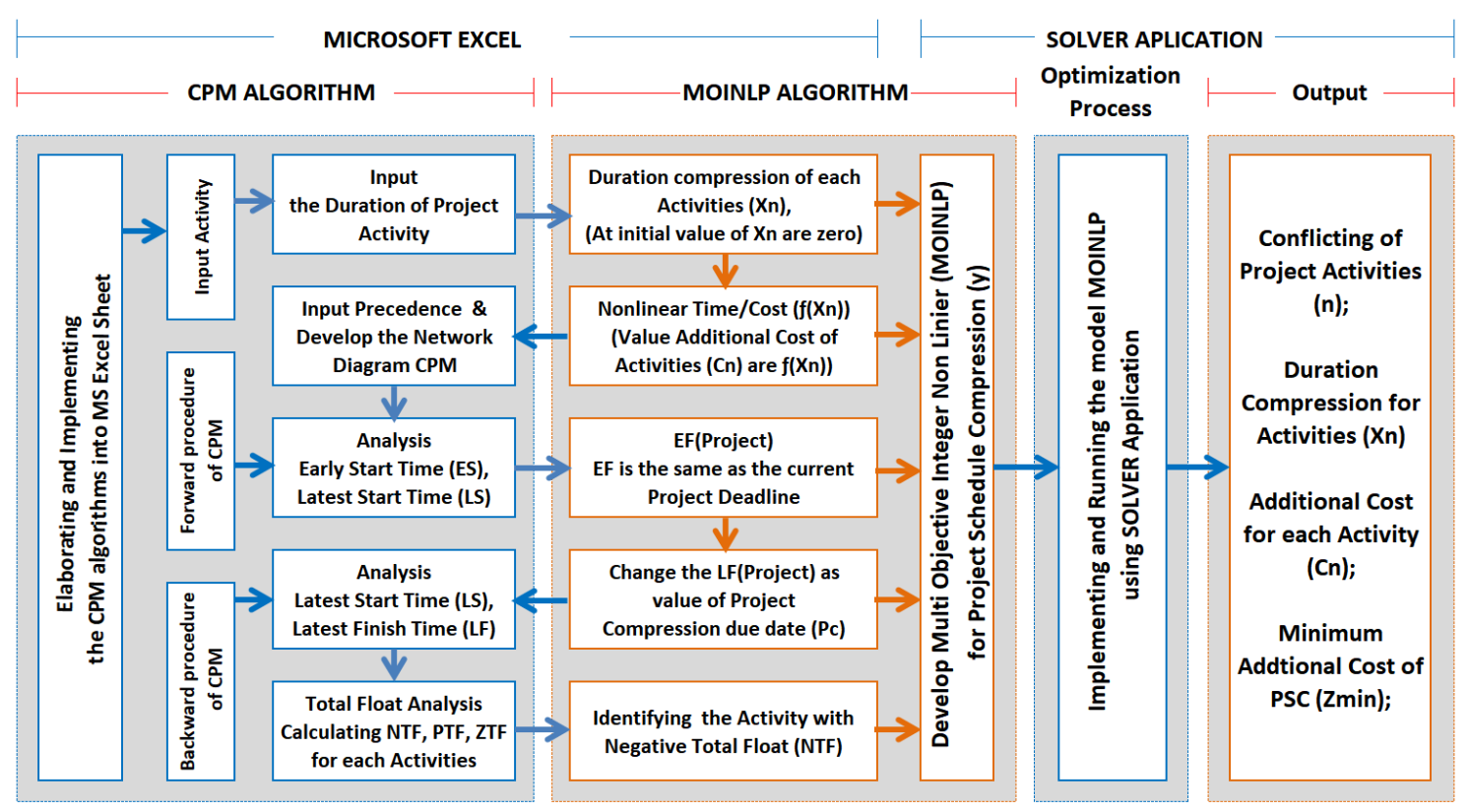

Figure 1. The framework of MOINLP for Project Scheduling Compression (PSC)

\subsection{The CPM Algorithm}

The algorithm for CPM refers to the forward and the backward procedure. The forward procedure of CPM is used to analyze Early Start (ES) and Earliest Finish (EF), while the backward procedure of CPM is used to determine Latest Start (LS), Latest Finish (LF). The CPM algorithm has been developed and applied in many fields for a long time and widespread as it was initiated by Du Pont Company, Kelley, and Walker [25], as the following formula from (1) to (10).

\subsubsection{The forward procedure of CPM algorithm}

a. The rule of the early start of each project activities are:

$$
\operatorname{ES}(n)=\operatorname{Max}\left\{\operatorname{ES}\left(n_{p}\right)+D_{n p} \mid n_{p} \in \text { set of immediate predecessors of activity } n\right\}
$$

b. At the initial node of a project (the starting time of a project) and the initial activities have no predecessor. Then, the rule of the early start time for each initial activity is 0 (zero).

$$
\text { if } \mathrm{n}_{\mathrm{p}} \text { is empty then, } \mathrm{ES}\left(\mathrm{n}_{-} \text {initial }\right)=0 \text { and }, \mathrm{ES}(\text { Project })=0
$$


c. At the end node of a project where there are no successors of activities. Then, the rule of early finish of each last activities are:

$$
\begin{aligned}
& \mathrm{EF}\left(\mathrm{n}_{-} \text {last }\right)=\operatorname{Max}\left\{\mathrm{EF}\left(\mathrm{n}_{-} \text {last }\right)+D_{n_{-} \text {last }} \mid \mathrm{n}_{\text {last }} \in \text { set of the last activities of a project }\right\} \\
& \mathrm{EF}(\text { Project })=\operatorname{Max}\left\{\mathrm{ES}\left(\mathrm{n}_{-} \text {last }\right) \mid \mathrm{n}_{\text {last }} \in \text { set of the last activities of a project }\right\}
\end{aligned}
$$

\subsubsection{The backward procedure of CPM algorithm}

a. At the end node of a project where there are no successors dependencies of activities. Then, the rule of the latest finish of each last activities are:

$$
\begin{aligned}
& \mathrm{LF}(\text { Project })=\mathrm{EF}(\text { Project }) \\
& \mathrm{LF}(\text { n_last })=\mathrm{LF}(\text { Project })
\end{aligned}
$$

b. The rule of the latest finish of each project activities are:

$$
L F(n)=\operatorname{Min}\left\{L F\left(n_{s}\right)+D_{n s} \mid n_{s} \in \text { set of immediate successors of activity } n\right\}
$$

c. At the initial node of the project (the starting time of a project) and the initial activities have no predecessor. Then, the rule of the early start time for each initial activity is 0 (zero).

$$
\begin{aligned}
& \text { if } \mathrm{n}_{\mathrm{p}} \text { is empty then, } \mathrm{LS}\left(\mathrm{n}_{-} \text {initial }\right)=0 \\
& \mathrm{LS}(\text { Project })=0
\end{aligned}
$$

\subsubsection{The Total Float Analysis of each activity in CPM}

$$
\mathrm{TF}(\mathrm{n})=\mathrm{LF}(\mathrm{n})-\mathrm{D}_{\mathrm{n}}-\mathrm{ES}(\mathrm{n})
$$

The multi-objective problem in project scheduling compression involving non-linear time/cost activity model to achieve the minimum target cost of the project will be analyzed using the data as illustrated in Table 1.

Table 1. Data of the project activities for PSC

\begin{tabular}{ccccccc}
\hline No & $\begin{array}{c}\text { Activities } \\
\text { ID } \\
(\mathrm{n})\end{array}$ & $\begin{array}{c}\text { Predecessor } \\
\left(\mathrm{n}_{\mathrm{p}}\right)\end{array}$ & $\begin{array}{c}\text { Successor } \\
\left(\mathrm{n}_{\mathrm{s}}\right)\end{array}$ & $\begin{array}{c}\text { Normal Duration } \\
(\text { Initial Duration) } \\
\left(\mathrm{D}_{\mathrm{n}}\right)\end{array}$ & $\begin{array}{c}\text { The maximum amount of } \\
\text { Compressing Duration Activity } \\
\left(\mathrm{X}_{\mathrm{n}} \text { max }\right)\end{array}$ & $\begin{array}{c}\text { Non-linear Time/Cost } \\
\text { Model of each Activity } \\
\mathrm{f}\left(\mathrm{X}_{\mathrm{n}}\right)\end{array}$ \\
\hline 1 & $\mathrm{~A}$ & - & $\mathrm{D}, \mathrm{E}$ & 12 & 9 & $37 \mathrm{x}_{\mathrm{A}}^{2}+\mathrm{x}_{\mathrm{A}}$ \\
2 & $\mathrm{~B}$ & - & $\mathrm{F}, \mathrm{H}$ & 12 & 9 & $30 \mathrm{x}_{\mathrm{B}}^{3}$ \\
3 & $\mathrm{C}$ & - & $\mathrm{L}$ & 25 & 20 & $2 \mathrm{x}_{\mathrm{C}}^{3}$ \\
4 & $\mathrm{D}$ & $\mathrm{A}$ & $\mathrm{G}, \mathrm{I}$ & 20 & 16 & $\mathrm{x}_{\mathrm{D}}^{3}+\mathrm{x}_{\mathrm{D}}^{2}+\mathrm{x}_{\mathrm{D}}$ \\
5 & $\mathrm{E}$ & $\mathrm{A}$ & $\mathrm{J}$ & 23 & 18 & $2 \mathrm{x}_{\mathrm{E}}^{3}-\mathrm{x}_{\mathrm{E}}^{2}$ \\
6 & $\mathrm{~F}$ & $\mathrm{~B}$ & $\mathrm{G}, \mathrm{I}$ & 8 & 6 & $2 \mathrm{x}_{\mathrm{F}}^{5}-\mathrm{x}_{\mathrm{F}}^{4}$ \\
7 & $\mathrm{G}$ & $\mathrm{D}, \mathrm{F}$ & $\mathrm{J}$ & 11 & 8 & $\mathrm{x}_{\mathrm{G}}^{4}+\mathrm{x}_{\mathrm{G}}$ \\
8 & $\mathrm{H}$ & $\mathrm{B}$ & $\mathrm{K}$ & 25 & 20 & $7 \mathrm{x}_{\mathrm{H}}^{2}$ \\
9 & $\mathrm{I}$ & $\mathrm{D}, \mathrm{F}$ & $\mathrm{K}$ & 8 & 6 & $\mathrm{x}_{\mathrm{I}}^{6}-2 \mathrm{x}_{\mathrm{I}}^{5}+3 \mathrm{x}_{\mathrm{I}}$ \\
10 & $\mathrm{~J}$ & $\mathrm{E}, \mathrm{G}$ & - & 18 & 14 & $5 \mathrm{x}_{\mathrm{J}}^{2}+5 \mathrm{x}_{\mathrm{J}}$ \\
11 & $\mathrm{~K}$ & $\mathrm{H}, \mathrm{I}$ & - & 15 & 12 & $2 \mathrm{x}_{\mathrm{K}}^{4}$ \\
12 & $\mathrm{~L}$ & $\mathrm{C}$ & - & 30 & 24 & $5 \mathrm{x}_{\mathrm{L}}^{2}$ \\
\hline
\end{tabular}

\section{RESULTS}

\subsection{Initial Network Diagram Scheduling}

Based on the information in Table 1, we construct the project network diagram using CPM analysis. This analysis gives the result of EF of 61 days as the normal project due date $\left(P_{n}\right)$ and a critical path consist of the critical activity of A, D, G, J, as shown in Figure 2. 


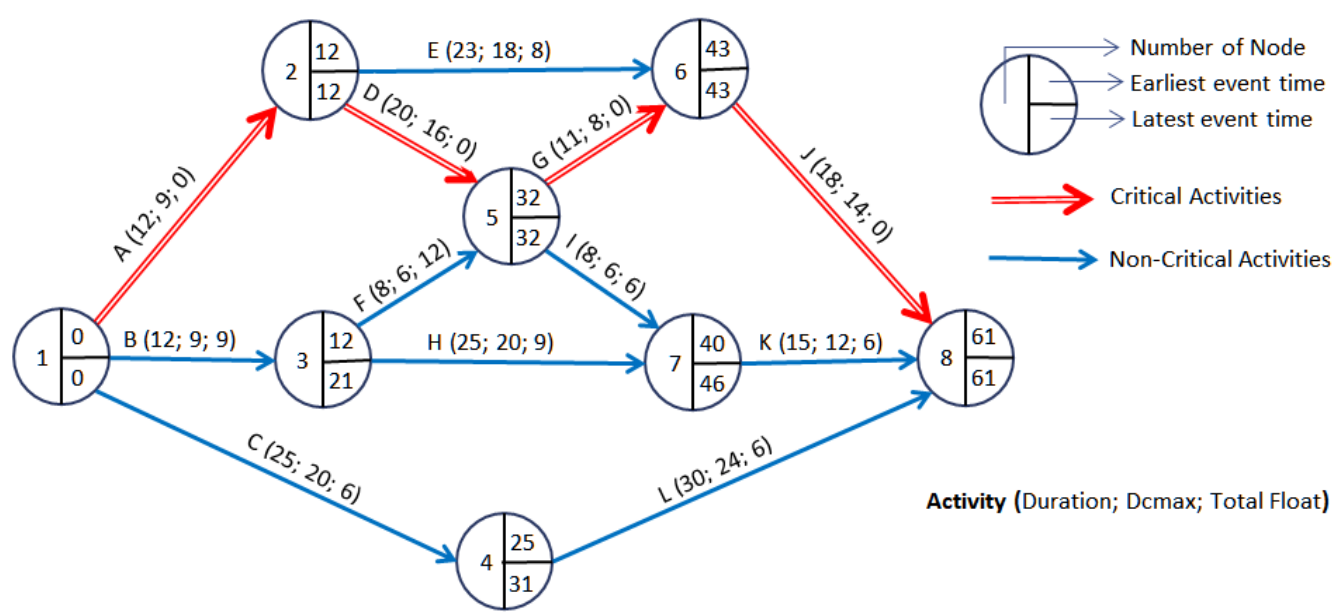

Figure 2. Network diagram for the normal project at the initial

\subsection{Identifying the Conflicting Objective using Negative Total Float (NTF)}

Several previous studies have suggested that the optimization problem solving of multi-objectives will involve a number of conflicting activity [19], [26]. Unfortunately, the study does not explain which one of the conflicting activities. We have developed a set procedure to identify the conflicting. We have replaced $\mathrm{LF}$ with $\mathrm{P}_{\mathrm{c}}$ in the network diagram system analysis as shown in Figure 3 to bring up the difference between LF and EF. This condition will show NTF on some activities indicated as conflicting activities that need to be satisfied to achieve the due date of the accelerated project. As an illustration of the value of NTF (on the activities of A, D, G, and J with NTF each of -6) that may occur due to y of 6 days, as shown in Figure 3. In the case of PSC for y of 1 to 12 days will give results to NTF and various conflicting activities, as shown in Table 2. The activities of $\mathrm{A}, \mathrm{D}, \mathrm{G}$, and $\mathrm{J}$ are combined activities to obtain the optimal solution and visible solution of PSC for y for 6 days, as shown in Table 3.

This analysis will contribute to understanding the combination of accelerated activity (conflicting activities) on PSC using MOINLP. The number of conflicting objectives may vary, depending on the network model and the number of PSC planned. In this study, we identify the activities that have experienced conflicting objective. In the actual implementation of the schedule, NTF conditions possibly occur. It is probably caused by a delay in the predecessor activity or caused by the activity that has been implemented later than the planned activity duration, especially in the critical activity. This condition is similar to the case of PSC, where the compressed duration of the activity is conditioned as a critical activity carried out faster than its normal time.

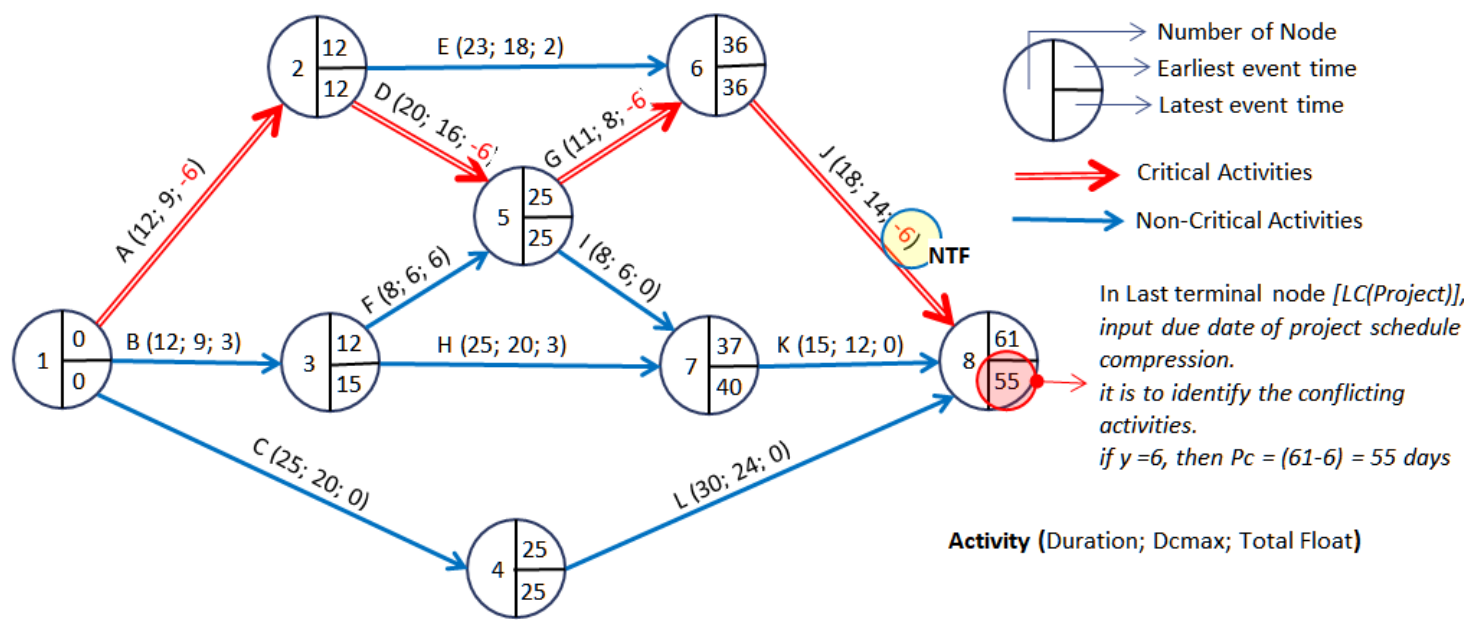

Figure 3. Project Network diagram with modification in the latest finish of CPM terminal node 
Under the initial analysis of the network diagram, the LF value in network diagram is the same as with its EF of 61 days (the initial due date of the project), as shown in Figure 2. After compressing the project schedule with y ( 0 to 12 days), as shown in Table 2 , shows some activities having to vary NTF. It is conducted by change LF in the terminal node to be Pc, for example as shown in Figure 3. Based on the results of $\mathrm{TF}_{\mathrm{c}}$ (55 days) on the Table 2, both negative and positive value, indicates that if the total float normal $\left(\mathrm{TF}_{\mathrm{n}}\right)$ of the activity is less than the value of $\mathrm{y}$ in PSC then the TF of the activity will be negative value (it will experience conflicting objective of activities function). We conclude that the greater the value of y will more conflicting activities and it NTF value. The example in Table 2 with cases 1 through 12 , indicating a change in the value of Total Float leading to an increasingly large NTF. NTF of some activities experiences an increase in both negative values and the number of conflicting activities along with the increasing of $\mathrm{y}$ in PSC, as shown in Table 2.

Table 2. The conflicting objective of PSC using MOINLP with y of 0 to 12 days

\begin{tabular}{|c|c|c|c|c|c|c|c|c|c|c|c|c|c|c|c|c|}
\hline \multirow[b]{2}{*}{$\begin{array}{l}\text { Cases of } \\
\text { Compres } \\
\text { sion }\end{array}$} & \multicolumn{3}{|c|}{ Project Information } & \multicolumn{12}{|c|}{ Total Float of Activities $\left(\mathrm{TF}_{\mathrm{c}}\right)$} & \multirow[b]{2}{*}{$\begin{array}{c}\text { Conflicting Objective } \\
\text { (Conflicting Activity of Project } \\
\text { Schedule) }\end{array}$} \\
\hline & $\begin{array}{c}\text { Initial } \\
\text { Due date } \\
\text { of Project } \\
\left(P_{n}\right) \\
\end{array}$ & $\begin{array}{c}\text { Project } \\
\text { Scheduling } \\
\text { Compression } \\
\left(y=P_{n}-P_{c}\right) \\
\end{array}$ & $\begin{array}{c}\text { Due date } \\
\text { after } \\
\text { Compression } \\
\left(P_{c}\right) \\
\end{array}$ & A & B & $\mathrm{C}$ & $\mathrm{D}$ & $\mathrm{E}$ & $\mathrm{F}$ & G & $\mathrm{H}$ & I & $\mathrm{J}$ & $\mathrm{K}$ & $\mathrm{L}$ & \\
\hline Initial & 61 & 0 & 61 & 0 & 9 & 6 & 0 & 8 & 12 & 0 & 9 & 6 & 0 & 6 & 6 & No \\
\hline Case 1 & 61 & 1 & 60 & -1 & 8 & 5 & -1 & 7 & 11 & -1 & 8 & 5 & -1 & 5 & 5 & $\mathrm{~A}, \mathrm{D}, \mathrm{G}, \mathrm{J}$ \\
\hline Case 2 & 61 & 2 & 59 & -2 & 7 & 4 & -2 & 6 & 10 & -2 & 7 & 4 & -2 & 4 & 4 & $\mathrm{~A}, \mathrm{D}, \mathrm{G}, \mathrm{J}$ \\
\hline Case 3 & 61 & 3 & 58 & -3 & 6 & 3 & -3 & 5 & 9 & -3 & 6 & 3 & -3 & 3 & 3 & $\mathrm{~A}, \mathrm{D}, \mathrm{G}, \mathrm{J}$ \\
\hline Case 4 & 61 & 4 & 57 & -4 & 5 & 2 & -4 & 4 & 8 & -4 & 5 & 2 & -4 & 2 & 2 & $\mathrm{~A}, \mathrm{D}, \mathrm{G}, \mathrm{J}$ \\
\hline Case 5 & 61 & 5 & 56 & -5 & 4 & 1 & -5 & 3 & 7 & -5 & 4 & 1 & -5 & 1 & 1 & $\mathrm{~A}, \mathrm{D}, \mathrm{G}, \mathrm{J}$ \\
\hline Case 6 & 61 & 6 & 55 & -6 & 3 & 0 & -6 & 2 & 6 & -6 & 3 & 0 & -6 & 0 & 0 & $\mathrm{~A}, \mathrm{D}, \mathrm{G}, \mathrm{J}$ \\
\hline Case 7 & 61 & 7 & 54 & -7 & 2 & -1 & -7 & 1 & 5 & -7 & 2 & -1 & -7 & -1 & -1 & $\mathrm{~A}, \mathrm{C}, \mathrm{D}, \mathrm{G}, \mathrm{I}, \mathrm{J}, \mathrm{K}, \mathrm{L}$ \\
\hline Case 8 & 61 & 8 & 53 & -8 & 1 & -2 & -8 & 0 & 4 & -8 & 1 & -2 & -8 & -2 & -2 & $\mathrm{~A}, \mathrm{C}, \mathrm{D}, \mathrm{G}, \mathrm{I}, \mathrm{J}, \mathrm{K}, \mathrm{L}$ \\
\hline Case 9 & 61 & 9 & 52 & -9 & 0 & -3 & -9 & -1 & 3 & -9 & 0 & -3 & -9 & -3 & -3 & $\mathrm{~A}, \mathrm{C}, \mathrm{D}, \mathrm{E}, \mathrm{G}, \mathrm{I}, \mathrm{J}, \mathrm{K}, \mathrm{L}$ \\
\hline Case 10 & 61 & 10 & 51 & -10 & -1 & -4 & -10 & -2 & 2 & -10 & -1 & -4 & -10 & -4 & -4 & $\mathrm{~A}, \mathrm{~B}, \mathrm{C}, \mathrm{D}, \mathrm{E}, \mathrm{G}, \mathrm{H}, \mathrm{I}, \mathrm{J}, \mathrm{K}, \mathrm{L}$ \\
\hline Case 11 & 61 & 11 & 50 & -11 & -2 & -5 & -11 & -3 & 1 & -11 & -2 & -5 & -11 & -5 & -5 & $\mathrm{~A}, \mathrm{~B}, \mathrm{C}, \mathrm{D}, \mathrm{E}, \mathrm{G}, \mathrm{H}, \mathrm{I}, \mathrm{J}, \mathrm{K}, \mathrm{L}$ \\
\hline Case 12 & 61 & 12 & 49 & -12 & -3 & -6 & -12 & -4 & 0 & -12 & -3 & -6 & -12 & -6 & -6 & $\mathrm{~A}, \mathrm{~B}, \mathrm{C}, \mathrm{D}, \mathrm{E}, \mathrm{G}, \mathrm{H}, \mathrm{I}, \mathrm{J}, \mathrm{K}, \mathrm{L}$ \\
\hline
\end{tabular}

Method for calculating Total Float of each activity after setting $\mathrm{P}_{\mathrm{c}}$ (the due date of Project scheduling Compression) uses the mathematical formulations as shown in formula (11).

$$
\mathrm{TF}_{\mathrm{c}}=\mathrm{TF}_{\mathrm{n}}-\mathrm{y}
$$

Where $\mathrm{TF}_{\mathrm{c}}$ is the Total Float of activity after the PSC (Total Float could be PTF, ZTF, and NTF); $\mathrm{TF}_{\mathrm{n}}$ is the initial Total Float of activity (the Total Float of activity before the PSC); and y is the compressed duration of the project.

\subsection{Developing the MOINLP based on the basic MOP for Project Scheduling Compression}

In this study, we apply the concept of Negative Total Float (NTF) to Multi-Objective Models, as a constraint that must be satisfied to solve the minimizing problem of the objective function. Developing a multi-objective model also refers to the MOLP model developed by Deckro [19]. The development of the model will be explained as follows:

1. The objective function (The Solver: target cell):

$$
\begin{aligned}
& \operatorname{Min} \mathrm{Z}(\mathrm{y})=\operatorname{Min} \sum_{\mathrm{n}=1}^{\mathrm{m}}\left(\left(\mathrm{f}\left(\mathrm{x}_{\mathrm{n}}\right) \mid \mathrm{x}_{\mathrm{n}} \in\left\{0,1,2,3, \ldots, \mathrm{x}_{\mathrm{n}} \max \right\}\right)\right. \\
& \operatorname{Min} \mathrm{Z}(\mathrm{y})=\operatorname{Min} \sum_{\mathrm{E}}\left(\left(37 \mathrm{x}_{\mathrm{A}}^{2}+\mathrm{x}_{\mathrm{A}}\right)+\left(30 \mathrm{x}_{\mathrm{B}}^{3}\right)+\left(2 \mathrm{x}_{\mathrm{C}}^{3}\right)+\left(\mathrm{x}_{\mathrm{D}}^{3}+\mathrm{x}_{\mathrm{D}}^{2}+\mathrm{x}_{\mathrm{D}}\right)+\right. \\
& \left(2 \mathrm{x}_{\mathrm{E}}^{3}-2 \mathrm{x}_{\mathrm{E}}^{2}\right)+\left(2 \mathrm{x}_{\mathrm{F}}^{5}-\mathrm{x}_{\mathrm{F}}^{4}\right)+\left(\mathrm{x}_{\mathrm{G}}^{4}+\mathrm{x}_{\mathrm{G}}\right)+\left(7 \mathrm{x}_{\mathrm{H}}^{2}\right)+\left(\mathrm{x}_{\mathrm{I}}^{6}-2 \mathrm{x}_{\mathrm{I}}^{5}+3 \mathrm{x}_{\mathrm{I}}\right)+\left(5 \mathrm{x}_{\mathrm{J}}^{2}+\right. \\
& \left.\left.5 \mathrm{x}_{\mathrm{J}}\right)+\left(2 \mathrm{x}_{\mathrm{K}}^{4}\right)+\left(5 \mathrm{x}_{\mathrm{L}}^{2}\right) \mid \mathrm{x}_{\mathrm{n}} \in\left\{0,1,2,3, \ldots, \mathrm{x}_{\mathrm{n}} \max \right\}\right)
\end{aligned}
$$

2. The variable of the model (The Solver: by changing cells), $x_{n}$ :

$$
\mathrm{x}_{\mathrm{A}} ; \mathrm{x}_{\mathrm{B}} ; \mathrm{x}_{C} ; \mathrm{x}_{\mathrm{D}} ; \mathrm{x}_{\mathrm{E}} ; \mathrm{x}_{\mathrm{F}} ; \mathrm{x}_{\mathrm{G}} ; \mathrm{x}_{\mathrm{H}} ; \mathrm{x}_{\mathrm{I}} ; \mathrm{x}_{\mathrm{J}} ; \mathrm{x}_{\mathrm{K}} ; \mathrm{x}_{\mathrm{L}}
$$


3. The constraints of the model (The Solver: subject to the constraints):

a. The compressed duration for each activity $\left(x_{n}\right) \geq 0$, it is a constraint of the non-negative.

$$
\mathrm{x}_{\mathrm{A}} ; \mathrm{x}_{\mathrm{B}} ; \mathrm{x}_{\mathrm{C}} ; \mathrm{x}_{\mathrm{D}} ; \mathrm{x}_{\mathrm{E}} ; \mathrm{x}_{\mathrm{F}} ; \mathrm{x}_{\mathrm{G}} ; \mathrm{x}_{\mathrm{H}} ; \mathrm{x}_{\mathrm{I}} ; \mathrm{x}_{\mathrm{J}} ; \mathrm{x}_{\mathrm{K}} ; \mathrm{x}_{\mathrm{L}} \geq 0
$$

This developed constraint is a non-negative constraint to ensure that the amount of compressed duration for each activity is greater than or equal to zero. The constraint is in line with the paper was developed by Deckro [19].

b. The additional cost for each activity $\left(C_{n}\right) \geq 0$, it is a constraint of the non-negative.

$$
\mathrm{C}_{\mathrm{A}} ; \mathrm{C}_{\mathrm{B}} ; \mathrm{C}_{\mathrm{C}} ; \mathrm{C}_{\mathrm{D}} ; \mathrm{C}_{\mathrm{E}} ; \mathrm{C}_{\mathrm{F}} ; \mathrm{C}_{\mathrm{G}} ; \mathrm{C}_{\mathrm{H}} ; \mathrm{C}_{\mathrm{I}} ; \mathrm{C}_{\mathrm{J}} ; \mathrm{C}_{\mathrm{K}} ; \mathrm{C}_{\mathrm{L}} \geq 0
$$

This developed constraint is a non-negative constraint to ensure that the additional cost due to the compressed duration for each activity is greater than or equal to zero. The constraint is in line with the paper was developed by Deckro [19].

c. The compressed duration for each the activities $\left(\mathrm{x}_{\mathrm{n}}\right) \leqq\left(\mathrm{x}_{\mathrm{n}} \max \right)$.

$$
\begin{aligned}
& \mathrm{x}_{\mathrm{A}} \leq 6 ; \mathrm{x}_{\mathrm{B}} \leq 6 ; \mathrm{x}_{\mathrm{C}} \leq 13 ; \mathrm{x}_{\mathrm{D}} \leq 10 ; \mathrm{x}_{\mathrm{E}} \leq 12 ; \mathrm{x}_{\mathrm{F}} \leq 4 ; \mathrm{x}_{\mathrm{G}} \leq 6 ; \mathrm{x}_{\mathrm{H}} \leq 13 ; \mathrm{x}_{\mathrm{I}} \leq \\
& 4 ; \mathrm{x}_{\mathrm{J}} \leq 12 ; \mathrm{x}_{\mathrm{K}} \leq 8 ; \mathrm{x}_{\mathrm{L}} \leq 16
\end{aligned}
$$

This constraint will ensure that the activities are not allowed over the limitation of the maximum amount of crashing [19].

d. The compressed duration for each activity $\left(x_{n}\right)=$ Integer. It is the integer requirement of duration reduction for the activity. This is the flexible function that could be removed if it is not the integer case.

$$
\mathrm{x}_{\mathrm{A}} ; \mathrm{x}_{\mathrm{B}} ; \mathrm{x}_{\mathrm{C}} ; \mathrm{x}_{\mathrm{D}} ; \mathrm{x}_{\mathrm{E}} ; \mathrm{x}_{\mathrm{F}} ; \mathrm{x}_{\mathrm{G}} ; \mathrm{x}_{\mathrm{H}} ; \mathrm{x}_{\mathrm{I}} ; \mathrm{x}_{\mathrm{J}} ; \mathrm{x}_{\mathrm{K}} ; \mathrm{x}_{\mathrm{L}}=\text { Integer }
$$

e. The earliest completion time of project $\geq$ Project compression due date.

This constraint arises from the replacement of the LC (project) in the last node (project terminal node) to be the PSC due date $\left(\mathrm{P}_{\mathrm{c}}\right)$. PSC due date is a target for project finish.

$$
\mathrm{EF}(\text { Project }) \leq \mathrm{P}_{\mathrm{c}}
$$

This constraint assures Early Finish in the terminal node (EF) must be less than or equal to the due date of Project scheduling compression $\left(\mathrm{P}_{\mathrm{c}}\right)[19]$

f. Negative Total Float (NTF) of each activity $\geq 0$ (zero). This constraint is to ensure the NTF in some activities must be more than or equal to zero. This constraint is one of model development in this paper.

$$
\mathrm{NTF}_{\mathrm{c}} \geq 0
$$

\subsection{Implementing MOINLP Model Using The Solver}

This study improves MOINLP by adding Negative Total Float (NTF) constraints, which indicates as a value that should be satisfied to achieve the expected PSC. The satisfaction of activities that have NTF is achieved by reducing the duration of the activity $\left(x_{n}\right)$. Some of the activity combinations can potentially be satisfied (reduced) to achieve PSC targets. The best combination of activity selection is the minimum total cost of some activities (as a minimum additional cost of the project) based on the time-cost function of the activity. Table 3 and Table 4 show the output PSC for y at 6 and 7 days (project duration reduction) using the MOINLP model simulated by the Solver. The output describes results with two categories, namely:

a. The optimal solution shows the minimum value of output objective.

b. The feasible solution is the result of the solution space and it is still not a minimum [27]. 
Table 3. The solution for MOINLP for PSC of 6 days (Project due date 55 days)

\begin{tabular}{|c|c|c|c|c|c|c|c|c|c|c|c|c|c|c|c|}
\hline \multirow{3}{*}{$\frac{\text { Activities }}{\mathrm{n}}$} & \multirow{3}{*}{$\begin{array}{c}\begin{array}{c}\text { Normal } \\
\text { Duration }\end{array} \\
\mathrm{D}_{\mathrm{n}}\end{array}$} & \multirow{3}{*}{$\frac{\text { Initial } \mathrm{TF}}{\mathrm{TF}_{\mathrm{n}}}$} & \multirow{3}{*}{$\begin{array}{c}\begin{array}{c}\mathrm{TF} \\
\text { crashing }\end{array} \\
\mathrm{TF}_{\mathrm{c}}\end{array}$} & \multirow{2}{*}{\multicolumn{3}{|c|}{$\begin{array}{l}\text { Optimal Solution } \\
\text { Mode } 1\end{array}$}} & \multicolumn{9}{|c|}{ Feasible Solution } \\
\hline & & & & & & & \multicolumn{3}{|c|}{ Mode 2} & \multicolumn{3}{|c|}{ Mode 3} & \multicolumn{3}{|c|}{ Mode 4} \\
\hline & & & & $\mathrm{x}_{\mathrm{n}}$ & $\mathrm{C}_{\mathrm{n}}$ & $\mathrm{TF}_{\mathrm{n}}$ & $\mathrm{x}_{\mathrm{n}}$ & $\mathrm{C}_{\mathrm{n}}$ & $\mathrm{TF}_{\mathrm{n}}$ & $\mathrm{X}_{\mathrm{n}}$ & $\mathrm{C}_{\mathrm{n}}$ & $\mathrm{TF}_{\mathrm{n}}$ & $\mathrm{X}_{\mathrm{n}}$ & $\mathrm{C}_{\mathrm{n}}$ & $\mathrm{TF}_{\mathrm{n}}$ \\
\hline A & 12 & 0 & -6 & 0 & 0 & 0 & 1 & 38 & 0 & 1 & 38 & 0 & 0 & 0 & 0 \\
\hline B & 12 & 9 & 3 & 0 & 0 & 3 & 0 & 0 & 3 & 0 & 0 & 3 & 0 & 0 & 3 \\
\hline $\mathrm{C}$ & 25 & 6 & 0 & 0 & 0 & 0 & 0 & 0 & 0 & 0 & 0 & 0 & 0 & 0 & 0 \\
\hline $\mathrm{D}$ & 20 & 0 & -6 & 2 & 14 & 0 & 4 & 84 & 0 & 5 & 155 & 0 & 6 & 258 & 0 \\
\hline $\mathrm{E}$ & 23 & 8 & 2 & 0 & 0 & 4 & 0 & 0 & 4 & 0 & 0 & 3 & 0 & 0 & 2 \\
\hline $\mathrm{F}$ & 8 & 12 & 6 & 0 & 0 & 10 & 0 & 0 & 7 & 0 & 0 & 6 & 0 & 0 & 6 \\
\hline $\mathrm{G}$ & 11 & 0 & -6 & 2 & 18 & 0 & 0 & 0 & 0 & 0 & 0 & 0 & 0 & 0 & 0 \\
\hline $\mathrm{H}$ & 25 & 9 & 3 & 0 & 0 & 3 & 0 & 0 & 3 & 0 & 0 & 3 & 0 & 0 & 3 \\
\hline I & 8 & 6 & 0 & 0 & 0 & 2 & 0 & 0 & 5 & 0 & 0 & 6 & 0 & 0 & 6 \\
\hline $\mathrm{J}$ & 18 & 0 & -6 & 2 & 30 & 0 & 1 & 10 & 0 & 0 & 0 & 0 & 0 & 0 & 0 \\
\hline $\mathrm{K}$ & 15 & 6 & 0 & 0 & 0 & 2 & 0 & 0 & 3 & 0 & 0 & 3 & 0 & 0 & 3 \\
\hline $\mathrm{L}$ & 30 & 6 & 0 & 0 & 0 & 0 & 0 & 0 & 0 & 0 & 0 & 0 & 0 & 0 & 0 \\
\hline Total & & & & 6 & 62 & & 6 & 132 & & 6 & 193 & & 6 & 258 & \\
\hline Due date of PSC & & & & 55 & & & 55 & & & 55 & & & 55 & & \\
\hline
\end{tabular}

Analyzing PSC with y of 6 days results in 4 activities with NTF, namely A, D, G and J activity. All of the NTF value for the A, D, G, and J activity is -6 . It explains that the four activities will experience conflicting objective with the maximum compressing is 6 days as a total compression (TC) of PSC with y of 6 days. This also applies to other modes (mode 1 to mode 4) with varying $x_{n}$, as shown in Table 3. Minimum condition of the additional cost for PSC is in mode $1(\mathrm{Cn}=62)$ as an optimal solution with compressing activity are successfully A (0 days), D (2 days), G ( 2 days), and $\mathrm{J}$ ( 2 days). The point in this case (y = 6 days), activities that do not have NTF will not occur compressing on the activity, as $\mathrm{x}_{\mathrm{n}}$ in Table 3 . It is clear that NTF has a correlation with the conflicting objective.

Using the same method as in Figure 3, analysis of NTF in the PSC of 7 days will result in the NTF values varying as in Table 4 . The solution in those modes (we only show 4 modes) shows the compressing activity $\left(x_{n}\right)$ following the NTF pattern with the value of $x_{n}$ are under a range of the absolute value of NTF $(|\mathrm{NTF}|)$. This condition will also have the same pattern for all of the $y$ values (the compressing number for PSC) in this study. We conclude that the value of $|\mathrm{NTF}|$ shows the maximum value that can be achieved by compressing activity $\left(x_{n}\right)$ of all planned PSC and all modes produced (both optimal and feasible solutions).

Table 4. The solution for MOINLP for PSC of 7 days (Project due date 54 days)

\begin{tabular}{|c|c|c|c|c|c|c|c|c|c|c|c|c|c|c|c|}
\hline \multirow{3}{*}{ Activities } & \multirow{3}{*}{$\begin{array}{l}\text { Normal } \\
\text { Duration }\end{array}$} & \multirow{3}{*}{$\begin{array}{c}\text { Initial } \\
\text { Total } \\
\text { Float }\end{array}$} & \multirow{3}{*}{ NTF } & \multirow{2}{*}{\multicolumn{3}{|c|}{$\begin{array}{l}\text { Optimal Solution } \\
\text { Mode } 1\end{array}$}} & \multicolumn{9}{|c|}{ Feasible Solution } \\
\hline & & & & & & & \multicolumn{3}{|c|}{ Mode 2} & \multicolumn{3}{|c|}{ Mode 3} & \multicolumn{3}{|c|}{ Mode 4} \\
\hline & & & & $x_{n}$ & $\mathrm{C}_{\mathrm{n}}$ & $\mathrm{TF}_{\mathrm{n}}$ & $x_{n}$ & $\mathrm{C}_{\mathrm{n}}$ & $\mathrm{TF}_{\mathrm{n}}$ & $x_{n}$ & $\mathrm{C}_{\mathrm{n}}$ & $\mathrm{TF}_{\mathrm{n}}$ & $\mathrm{X}_{\mathrm{n}}$ & $\mathrm{C}_{\mathrm{n}}$ & $\mathrm{TF}_{\mathrm{n}}$ \\
\hline $\mathrm{A}$ & 12 & 0 & -7 & 0 & 0 & 0 & 0 & 0 & 0 & 2 & 150 & 0 & 4 & 596 & 0 \\
\hline B & 12 & 9 & 2 & 0 & 0 & 2 & 0 & 0 & 2 & 0 & 0 & 2 & 0 & 0 & 2 \\
\hline $\mathrm{C}$ & 25 & 6 & -1 & 1 & 2 & 0 & 1 & 2 & 0 & 0 & 0 & 0 & 1 & 2 & 1 \\
\hline $\mathrm{D}$ & 20 & 0 & -7 & 3 & 39 & 0 & 3 & 39 & 0 & 2 & 14 & 0 & 3 & 39 & 0 \\
\hline $\mathrm{E}$ & 23 & 8 & 1 & 0 & 0 & 3 & 0 & 0 & 2 & 0 & 0 & 5 & 0 & 0 & 5 \\
\hline $\mathrm{F}$ & 8 & 12 & 5 & 0 & 0 & 9 & 0 & 0 & 9 & 0 & 0 & 8 & 0 & 0 & 5 \\
\hline G & 11 & 0 & -7 & 2 & 18 & 0 & 3 & 84 & 0 & 1 & 2 & 0 & 0 & 0 & 0 \\
\hline $\mathrm{H}$ & 25 & 9 & 2 & 0 & 0 & 2 & 0 & 0 & 2 & 0 & 0 & 2 & 0 & 0 & 2 \\
\hline I & 8 & 6 & -1 & 0 & 0 & 2 & 0 & 0 & 2 & 0 & 0 & 3 & 0 & 0 & 6 \\
\hline $\mathrm{J}$ & 18 & 0 & -7 & 2 & 30 & 0 & 1 & 10 & 0 & 2 & 30 & 0 & 0 & 0 & 0 \\
\hline $\mathrm{K}$ & 15 & 6 & -1 & 0 & 0 & 2 & 0 & 0 & 2 & 0 & 0 & 2 & 0 & 0 & 2 \\
\hline $\mathrm{L}$ & 30 & 6 & -1 & 0 & 0 & 0 & 0 & 0 & 0 & 1 & 5 & 0 & 1 & 5 & 1 \\
\hline Total & & & & 8 & 89 & & 8 & 135 & & 8 & 201 & & 9 & 642 & \\
\hline Due date of & & & & 54 & & & 54 & & & 54 & & & 54 & & \\
\hline
\end{tabular}

\section{DISCUSSION}

\subsection{The important role of Negative Total Float (NTF) in MOP}

This paper presents the NTF role to attain the conflicting objectives of activity in order to achieve the PSC. The result of the conflicting objective in MOINLP of a PSC as shown in Table 2 shows there is a correlation of NTF value with the maximum reduction of the activities for both optimal and feasible solution of MOINLP for PSC as shown $x_{n}$ in Table 3 and Table 4. As an illustration for a PSC with a value of y of 7 
days having a conflicting activity are A, C, D, G, I, J, K, and L with NTF respectively are - $7,-1,-7,7,-1,-7$, -1 , and -1 as shown in Table 4 . In Table 4 shows that the PSC will be satisfied by compressing a number combination of some or all the project activities (A, C, D, G, I, J, K, and L activities), with a value of $x_{n}$ are not exceeding its NTF value. It is a novelty of this research where NTF could be an automatic maximum value of the activity duration reduction, although we do not specify a maximum value of the activity duration reduction $\left(x_{n} \max \right)$. Thus, this study formulates the $\mathrm{X}_{\mathrm{n}}$ Variable (the number of activity duration reduction) has a constraint as formula (21).

$$
\mathrm{X}_{\mathrm{n}} \leq \operatorname{Minimum}\left(|\mathrm{NTF}| \text { or } x_{n} \max \right)
$$

The formula (21) shows us that $x_{n} \max$ will not be achieved if the NTF absolute less than $x_{n} \max$. It is important to understand it regarding how to develop the the maximum value of the activity duration reduction $\left(x_{n} \max \right)$. The NTF absolut could be a control for $x_{n}$ max of model multi objective. The NTF could be an automatic of $x_{n}$ max in MOP model. This differs from the Deckro [19] and the same other research which do not concern toward the NTF as a parameter considered. The negative float concept (NF) has also been introduced by Lim's paper which states that NF is the amount of duration of activity that can be reduced without affecting the completion time of the project [16]. However, the Lim's paper [16] does not explain about the type of float used in his research. Meanwhile, Su's paper introduce negative of interference float [28]. This is a contrast to the NTF (negative total float) concept presented in this paper, where the NTF must be performed to conduct the Project Scheduling Compression (PSC) by changing the Latest Finish in terminal node of network diagram with $P_{c}$ value (due date of PSC), as shown in Figure 3. In this paper, we also introduce the important role in conducting multi objective to solve PSC problem.

\subsection{Implementing the basic MOP Model as MOINLP}

The model developed in this study refers to the Deckro model [19] as a basic model of MOP. However, this proposed MOINLP model has additional constraints, as shown in Formula (20), which has a significant effect on solving more complex PSC problems (it can solve problems with high-level variables). This condition indicates that the formula (20), as NTF constraint, is significant to improve the basic model. This is in line with research states that the float-path theory to solve the time-cost trade-off problem, although the research uses negative of interference float [28]. The principle of developing this MOINLP model is creating an unbalanced condition of Total Float (which needs to be satisfied) by manipulating the negative value of the total float. We see an opportunity to manipulate the Total Float by replacing the Latest Finish (LF) value on the terminal node of the network diagram with the $P_{c}$ value (due date of project compression), as shown in Figure 3. Choosing the right activity, we use the Solver Application as an optimization tool to eliminate NTF by reducing the duration of the activity. Based on this condition, we define the NTF as a basis to reduce the activity duration to achieve due date of the project schedule compression. Here we argue that problem solving of MOP for PSC case by involving the NTF is the key point to improve a MOP as MOINLP model. The conclusion of this study have shown that the classic model still has an important role to solve complex problems which it can compensate for more sophisticated MOP techniques.

Our presumption, this MOINLP model will give the optimization process faster than the earlier model to achieve an optimal solution. This is a future research to assess the time length of the itration optimization process, for both of discrete model or even distribution duration model [29], to reach the optimal solution of a PSC problem. Based on these results indicate that there is a relationship between NTF, as a constraint on the model developed in this paper, with both the optimal solution and feasible solution. The solution indicates the importance to use NTF on the model developed, especially in this study. Some of them, we can describe here are:

1. Each activity with NTF value is the conflicting objective of MOINLP for PSC case.

2. The obsolete value of NTF $(|\mathrm{NTF}|)$ is maximum value that can be achieved by the compressing activity (in case there is no maximum limit specified for the compressing activity, see $\mathrm{X}_{\mathrm{n}} \max$ in Table 1).

3. In the case of PSC, the activity duration reduction cannot decrease but it will increase or constant in line with increasing of PSC. The explanation is, the value of $x_{n}$ (duration reduction of activity) caused by of $y$ (value of the PSC) is more or equal then $x_{n}$ caused by $y-1$ (it could be compared on Table 3 and Table 4). This PSC case has a difference from the product/material mix case where it variable could be up and down in line with the increase it target, like the case in [30].

\section{CONCLUSION}

The NTF could be used to identify the conflicting objective in the PSC cases. The combination of activities having NTF will compete for one to each other to achieve the minimum additional cost of the 
project compression. It should be conducted without ignoring the principles of CPM and feasible of all constraints of MOINLP. NTF could be manipulated by replacing the Latest Finish (LF) value on the terminal node of the network diagram with the $P_{c}$ value (due date of project compression) to know which one of the duration of activity are reduced. In this paper, we increase the performance of the MOP basic model to solve the PSC complex problem by introduce the MOINLP concept. Involving the NTF in MOINLP have an important role and a key point to improve a MOINLP.

Negative Total Float (NTF) can be manipulated by replacing the value of the Latest Finish (LF) in a terminal node of project network diagram as the due date of Project scheduling Compression $\left(P_{c}\right)$. For the purpose of conducting the PSC, the $P_{c}$ certainly has a smaller value than the Earlier Finish of Normal Project (EF). These differences can generate NTF on some or all of the activity. NTF recovery can be done by reducing the amount of duration of the activity on the corresponding path. This is a logic thing in PSC. Base on the condition, we define that the Negative Total Float (NTF) is the maximum value for reducing the activity duration to achieve due date of the Project scheduling Compression

\section{ACKNOWLEDGMENTS}

The Authors would like to appreciate various parties involved in this research, especially to Director of Reinstate, Staff of CEM Laboratory - Civil Engineering of Syiah Kuala University.

\section{REFERENCES}

[1] Fachrurrazi, S. Husin, Munirwansyah, and Husaini, "The Subcontractor Selection Practice using ANN-Multilayer," Int. J. Technol., vol. 8, no. 4, p. 761, Jul. 2017.

[2] D. A. Noyce and A. S. Hanna, "Planned schedule compression concept file for electrical contractors," J. Constr. Eng. Manag., vol. 123, no. 2, pp. 189-197, Jun. 1997.

[3] R. M. W. Horner and B. T. Talhouni, "Effects of Accelerated Working, Delays and Distruption [ie Disruption] on Labour Productivity," Chartered Institute of Building, 1996.

[4] C.-K. Chang, A. S. Hanna, J. A. Lackney, and K. T. Sullivan, "Quantifying the impact of schedule compression on labor productivity for mechanical and sheet metal contractor," J. Constr. Eng. Manag., vol. 133, no. 4, pp. 287296, Apr. 2007.

[5] P. Ballesteros-Pérez, "Modelling the boundaries of project fast-tracking," Autom. Constr., vol. 84, pp. 231-241, Dec. 2017.

[6] A. Kanda and U. R. K. Rao, "A network flow procedure for project crashing with penalty nodes," Eur. J. Oper. Res., vol. 16, no. 2, pp. 174-182, May 1984.

[7] N. Georges, N. Semaan, and J. Rizk, "Crash : an Automated Tool for Schedule Crashing," Int. J. Sci. Environ. Technol., vol. 3, no. 2, pp. 374-394, 2014.

[8] A. El Yamami, K. Mansouri, M. Qbadou, and E. H. Illousamen, "Multi-objective IT project selection model for improving SME strategy deployment," Int. J. Electr. Comput. Eng., vol. 81, no. 2, pp. 1102-1111, Apr. 2018.

[9] Fachrurrazi, S. Husin, N. Malahayati, and Irzaidi, "Identifying inaccuracy of MS Project using system analysis," IOP Conf. Ser. Mater. Sci. Eng., vol. 352, no. 1, p. 012036, May 2018.

[10] F. Fachrurrazi, "The End User Requirement for Project Management Software Accuracy," Int. J. Electr. Comput. Eng., vol. 8, no. 2, pp. 1112-1121, Apr. 2018.

[11] A. Faruq, M. F. Nor Shah, and S. S. Abdullah, "Multi-objective Optimization of PID Controller using Pareto-based Surrogate Modeling Algorithm for MIMO Evaporator System," Int. J. Electr. Comput. Eng., vol. 8, no. 1, p. 556, Feb. 2018

[12] J. Mote, D. L. Olson, and M. A. Venkataramanan, "A comparative multiobjective programming study," Math. Comput. Model., vol. 10, no. 10, pp. 719-729, Jan. 1988.

[13] R. S. Jürgen Branke, Kalyanmoy Deb, Kaisa Miettinen, Multiobjective Optimization: Interactive and Evolutionary Approaches. Springer-Verlag, 2008.

[14] D. E. Bell, R. L. Keeney, and H. Raiffa, "Conflicting objectives in decisions," Conflicting Object. Decis., pp. 298322, 1977

[15] D. Dubois, H. Fargier, and V. Galvagnon, "On latest starting times and floats in activity networks with ill-known durations," Eur. J. Oper. Res., vol. 147, no. 2, pp. 266-280, Jun. 2003.

[16] A. Lim, H. Ma, B. Rodrigues, S. Teck Tan, and F. Xiao, "New concepts for activity float in resource-constrained project management," Comput. Oper. Res., vol. 38, no. 6, pp. 917-930, Jun. 2011.

[17] K. G. Lockyer and J. Gordon, Project management and project network techniques, vol. 7. Pearson Education, 2005

[18] B. H. Reich, S. Y. Wee, and W. Siew Yong, "Searching for Knowledge in the PMBOK Guide," Proj. Manag. J., vol. 37, no. 2, pp. 11-26, 2006.

[19] R. F. Deckro and J. E. Hebert, "A multiple objective programming framework for tradeoffs in project scheduling," Eng. Costs Prod. Econ., vol. 18, no. 3, pp. 255-264, Jan. 1990.

[20] A. Francis and S. Morin-Pepin, "The Concept of Float Calculation Based on the Site Occupation using the Chronographical Logic," in Procedia Engineering, vol. 196, pp. 690-697, 2017.

[21] J. M. Henderson and R. E. Quant, Microeconomic Theory: A Mathematical Approach. McGraw-Hill, 1980

[22] A. Ishizaka and P. Nemery, Multi-Criteria Decision Analysis: Methods and Software. John Wiley \& Sons, 2013. 
[23] K. Deb, "Multi-objective Optimisation Using Evolutionary Algorithms: An Introduction," in Multi-objective Evolutionary Optimisation for Product Design and Manufacturing, London: Springer London, pp. 3-34, 2011.

[24] Fachrurrazi, Y. Away, and S. Husin, "The weights detection of multi-criteria by using Solver," Int. J. Electr. Comput. Eng., vol. 7, no. 2, pp. 858-868, Apr. 2017.

[25] J. E. Kelley and M. R. Walker, "Critical-path planning and scheduling," in Papers presented at the December 1-3, 1959, eastern joint IRE-AIEE-ACM computer conference on - IRE-AIEE-ACM '59 (Eastern), pp. 160-173, 1959.

[26] S. K. Gachhayat, S. K. Dash, and P. Ray, "Multi Objective Directed Bee Colony Optimization for Economic Load Dispatch With Enhanced Power Demand and Valve Point Loading," Int. J. Electr. Comput. Eng., vol. 7, no. 5, p. 2382, Oct. 2017.

[27] V. Cacchiani and C. D'Ambrosio, "A branch-and-bound based heuristic algorithm for convex multi-objective MINLPs,” Eur. J. Oper. Res., vol. 260, no. 3, pp. 920-933, Aug. 2017.

[28] Z. X. Su, J. X. Qi, and H. Y. Wei, "A float-path theory and its application to the time-cost tradeoff problem," $J$. Appl. Math., vol. 2015, pp. 1-17, Feb. 2015.

[29] F. Fachrurrazi, A. Abdullah, Y. Away, and T. B. Aulia, "Estimating the normal duration using normal Production Rate per Day (PRPD) of project activity,” MATEC Web Conf., vol. 197, p. 10004, Sep. 2018.

[30] R. Kia, H. Shirazi, N. Javadian, and R. Tavakkoli-Moghaddam, "A multi-objective model for designing a group layout of a dynamic cellular manufacturing system," J. Ind. Eng. Int., vol. 9, no. 1, p. 8, Dec. 2013.

APPENDIX:

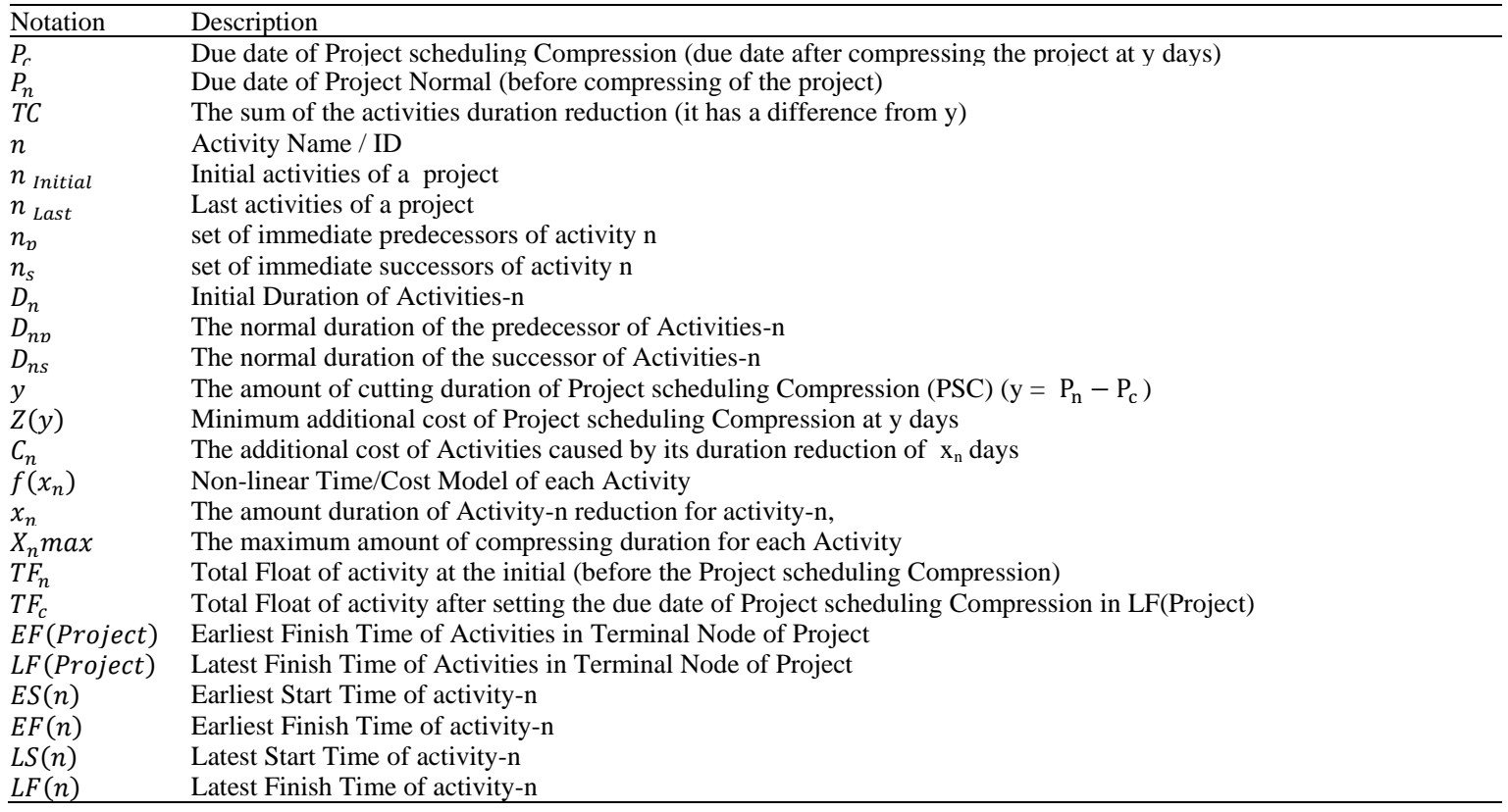

